\title{
СТУДЕНТСЬКІ БУДІВЕЛЬНІ ЗАГОНИ: КРИЗА 1980-Х ТА СПРОБИ ВІДНОВЛЕННЯ (НА ПРИКЛАДІ СТУДЕНТСЬКИХ БУДІВЕЛЬНИХ ЗАГОНІВ ХАРКІВЩИНИ)
}

У статті на основі широкого комплексу джерел проаналізовано основні досягнення студентських будівельних загонів (СБЗ) та вплив результату їх діяльності на розвиток народного господарства СРСР. На прикладі діяльності СБЗ вищих навчальних закладів м. Харкова розкрито причини появи кризових явищ, які привели до занепаду иьвого молодіжного руху. Авторка досліджує основні тенденції щзодо відновлення активної діяльності молодіжсни об'єднань як трудового резерву у вирішенні сочіально-економічних проблем як в Україні, так і в сучасному світі.

Ключові слова: студентські будівельні загони, вищі навчальні заклади, иілина, кризові явища, формалізм.

In the article, on the basis of a wide range of sources, the main achievements of student construction units (SCU) and the impact of the result of their activity on the development of the national economy of the USSR are analyzed. On the example of the activity of the SCU of higher educational institutions of Kharkiv, the causes of the crisis phenomen at what led to the decline of this youth movement are revealed. The author examines the main trends both in Ukraine and in the modern world to resume intense activity of youth associations as a labour reserve in socio-economic problems solving.

Students of Kharkiv higher educational institutions became active participants of the movement. The starting point of the student construction movement in Kharkiv region can be considered 1956, when the first detachments of virgin students were formed from volunteers in order not only to help gather a rich harvest, but also to begin construction of residential, industrial and agricultural facilities.

The main reason for the decline of the SCU was the economic situation in the country in the early 1990s, which led to the decline of the main sectors of the economy that provided the activities of labor detachments.

Based on the analysis of a wide range of sources, it can be concluded that the study of the history of the student construction movement remains one of the important areas of historical research, thus avoiding mistakes in the organization of the youth movement today. malism.

Keywords: student construction units, higher education institutions, virginsoil, crisis phenomena, for-

Постановка проблеми. В умовах реформації соціально-економічного розвитку країни особливого значення набуває досвід зародження й генезису студентських будівельних загонів 60-80-х років XX століття, які стали вирішальною рушійною силою у відбудові народного господарства в СРСР.

Сьогодні молодь, як завжди, стоїть в авангарді суспільно значущих перетворень і досвід, набутий у 1960-80-х роках, поновому трансформується на нове покоління. Саме тому актуальним є вивчення причин занепаду цього руху, адже це дозволить запобігти недолікам в організації і взаємодії із сучасними молодіжними трудовими загонами, які утворюються на основі досвіду студентських будівельних загонів.

Аналіз актуальних досліджень і публікацій. Фундаментом дослідження студентських будівельних загонів стали робо- ти Є.Ф. Артем'єва, одного 3 перших в СРСР дослідників руху студентських будівельних загонів [1]. I хоча для перших дослідників цього явища було притаманним висвітлення тільки його позитивних аспектів під керівництвом комсомольських і партійних структур, усе ж таки автор розкрив низку проблем в організації третього трудового семестру. Важливими були дослідження Ю. П. Платонова, спрямовані на вивчення подолання конфліктів у загонах та наростання тенденції щодо поступової втрати основних принципів добровільного формування студентських загонів [18].

У гонитві за загальною цифрою «охоплення» комсомольські організації прийшли до «добровільно-примусового» принципу формування загонів [19].

Зрозуміло, негативні тенденції в цьому процесі були відображенням наростання 
кризових явищ у суспільстві. Про необхідність перебудови стилю й форм роботи комсомолу, відмови від «валового підходу», який довго спрацьовував, наголошувалося в монографії В. В. Бовкуна [3].

Серед сучасних досліджень кризових явищ у студентських будівельних загонах на особливу увагу заслуговують роботи С. П. Іваненкова та I. П. Сазононова [11]. Грунтовний аналіз кризових явищ викладено в колективній монографії «Студент XXI століття», яка вийшла під редакцією В. І. Астахової [23]. Не можна не виокремити колективну працю відомих соціологів В. І. Чупрова і Ю. А. Зубока за участю англійського історика К. Уільямса «Молодь в суспільстві ризику»,опубліковану в 2001 р. [25]. Новий підхід до аналізу діяльності СБЗ відображено в роботах О. Л. Рябченко [21] та дисертаційній роботі Р. С. Ралка [20].

Формулювання цілей статті. Проаналізувати кризові явища, що виникали в студентських будівельних загонах і стали причиною їх занепаду та розкрити основні тенденції щодо відродження цього молодіжного руху.

Виклад основного матеріалу. Сьогодні існують різні й найчастіше абсолютно протилежні думки 3 приводу необхідності застосування досвіду студентських будівельних загонів на сучасному етапі. Для того, щоб детальніше розібратися в необхідності й раціональному залученні студентства до вирішення сучасних соціально-економічних питань нам необхідно звернутися до причин появи СБЗ.

У повоєнний період у країні відбувалася аграрна криза. У 1950-х роках виробництво зерна не досягало довоєнного рівня. Через катастрофічне положення в сільському господарстві не відбувалося й стрімкого розвитку інших сфер економіки. У 1953 році ЦК КПРС на вересневому пленумі оголосив курс на проведення реформ у сільському господарстві. Першими кроками стали списання заборгованості за недопостачання продуктів 3 колгоспів та зменшення планових показників [14, с. 321].

Також відбувся перегляд заготівельних цін на сільгосппродукцію, зниження податків на присадибні господарства та лі- квідація сталінських поборів на фруктові дерева та ягідні кущі. У 1950-х роках сільське господарство поволі почало давати прибуток, але збільшення виробництва не відбулося, адже необхідно було залучити значні капіталовкладення.

3 метою інтенсивного розвитку сільського господарства в 1954 році Пленум ЦК КПРС прийняв рішення про освоєння цілинних і перелогових земель Казахстану, Сибіру, а також на Уралі й Північному Кавказі. Уже в 1956 році цілинні землі дали 50 \% валового продукту. Продовольче питання, здавалося б, можна було вважати вирішеним. Але відсутність наукового підходу швидко призвела до виснаження грунтів цілинних земель, що в результаті спричинило зниження урожайності та збільшення собівартості цілинної пшениці на $20 \%$ у порівнянні з усім СРСР.

Окрім завдання подолання аграрної кризи, перші загони студентів як резерв трудової сили успішно були задіяні для підйому промисловості й на грандіозних, масштабних новобудовах народного господарства.

Керівництво КПРС звернулося в 1956 році до комсомольських організацій із закликом направити кращих представників радянської молоді на Північ і в східні райони країни для будівництва електростанцій, металургійних, хімічних, нафтопереробних і машинобудівних заводів та інших об'єктів народного господарства. Одна за одною виростали комсомольські новобудови Братська, Кременчуцька, Дніпродзержинська ГЕС, 37 комсомольських шахт на Донбасі, металургійний завод в Казахстані, Криворізький збагачувальний комбінат, гідростанції на Волзі й Дніпрі, нафтопровід «Дружба» й багато інших.

Активними учасниками цього руху стали й студенти Харківських вищих навчальних закладів. Відправною точкою студентського будівельного руху на Харківщині можна вважати 1956 рік, коли на офіційне звернення ЦК ВЛКСМ перші загони студентів-цілинників були сформовані 3 добровольців для того, щоб не тільки допомогти зібрати багатий цілинний врожай, а й розпочати будівництво житлових, промислових і сільськогосподарських об'єктів. 
Так, 2 липня 1956 року в Ніжинський радгосп Рузаєвського району Кокчетавської області відправився трьохтисячний загін студентів Харкова, у тому числі й 94 посланці Харківського інституту інженерів комунального будівництва [24, с. 43-56].

Тільки 3 1958-го по 1960-й рр. у Казахстані були побудовані 1 тис. будинків культури, понад 600 бібліотек, 1110 культурно-побутових об'єктів [17,с. 225-231].

Кожного року Харків проводжав студентські ешелони в Красноярський край, Камчатську область, Якутію, Іркутську, Магаданську області, Хабаровський край, на Чукотку тощо [9, с. 13].

Географія студентських будівельних загонів Харківщини, високі показники виробничої діяльності - усе це є беззаперечним фактом їх вагомого внеску в соціальноекономічний розвиток держави.

Дослідники історії СБЗ стверджують, що початком кризи студентських будівельних загонів став кінець 1970-х початок 1980-х років, в період пізнього застою, коли чітко намітилися негативні тенденції в організаційній діяльності цього руху $[24$, c. 79,87$]$.

Це був неоднозначний період в історії СБЗ. 3 одного боку цей рух постійно розширює свою активну діяльність і збільшує кількість його учасників. Так Харківський обласний будівельний загін розширює географію своєї участі і в другій половині 80-х років буд загони виїжджали в Тюмень, Новий Уренгой, Республіку Комі, Красноярський край, Кустанайську область Казахстану, а також закордон у такі країни, як Німеччина, Польща, Угорщина [24, с. 86].

Чисельність учасників по всій країні зростала, і в 1985 році було досягнуто рекордного показника - 830 тис. чол. Не відставав у показниках і Харківський обласний загін: у 1986 році він нараховував 407 лінійних загонів, сформованих із студентів, а в 1987 році таких загонів уже було 526 [24, c. 83].

3 іншого боку, відповідно до соціологічного опитування, проведеного в 11 вузах СРСР на початку $1980-x$ років, простежується стрімке падіння престижу популярності СБЗ в молодіжному середовищі. Опитувані називають цілий ряд причин цього явища. Так 33,2 \% заявили про порушення принципу добровільності під час формування СБ3; 33,8 \% не влаштовували постійні простої під час роботи, умови праці й побуту; 34,9 \% акцентували увагу на відсутності можливості обрати роботу, що відповідала б їхнім інтересам та профілю; $27,2 \%$ наголошували на недоліках в оплаті праці, які не гарантували отримання всіх зароблених коштів [24, с. 75-76].

На початку 1980-х років у всіх напрямах діяльності студентських будівельних загонів негативним явищем $\epsilon$ формалізм, бюрократизація й криза довіри молоді до вертикалі управління СБЗ. Цей висновок підтверджується даними вищезгаданого дослідження. Винними в порушеннях та кризових явищах СБЗ студенти вважали керівників господарств, які організовували прийом будзагонів (48,4 \%); міністерства й відомства (18\%); комітети комсомолу (29,7 \%); керівників лінійних студентських загонів (13,9\%); партійні й радянські органи $(10,5 \%)$ [22, с. $75-76]$.

Замість активного вирішення проблем і прийняття конструктивних дій керівництво посилює бюрократичний апарат і продовжує нарощувати кількісні показники у видачі нормативних, рекомендаційних та інших документів. Наприклад, у листі до обласних, крайових штабів СБЗ від 13 січня 1983 року ЦК ВЛКСМ наголошує на необхідності забезпечити кожен зональний загін такими документами:

1. Інструкція про порядок визначення готовності лінійних загонів до виїзду на місця дислокації (згідно з Постановою ЦШ СБЗ ЦК ВЛКСМ (травень 1980 р.).

2. Методика проведення перевірок фінансово-господарської діяльності лінійних студентських загонів.

3. Приблизний календарний план спільних дій студентських будівельних загонів та комсомольських організацій по ефективному проведенню суспільно-політичної роботи [4, арк. 4].

Формалізацію цього процесу наочно демонструє лист ЦК ВЛКСМ від 29 червня 1984 року. У ньому рекомендується: «3 метою ефективного контролю за ходом літньо-осінніх робіт студентів встановити 35 липня по 25 вересня чергування з 8:00 до 
23:00 год. в обласних і цілодобово в зональних штабах. Про хід трудового семестру інформувати Центральний штаб щопонеділка у відповідно визначені години для кожної області. Інформація не повинна займати більше 5-6 хв.» тощо [5, арк. 109].

Неймовірна кількість паперової роботи, розписані плани - від щоденних по напрямах діяльності до перспективних, звіти, які часто дублювали інформацію, аналіз звітів і висновки щодо неякісної їх подачі, не за шаблоном чи без того чи іншого погодження приводить Центральний штаб до необхідності видавати нову кількість інструктивних листів щодо поліпшення ведення документації СБЗ і навіть змушує зробити висновок, що всі ці інструкції не полегшують роботи лінійних штабів, які не в змозі вже розібратися в графіках подачі паперів у різні інстанції [5, арк. 12].

Збільшилася кількість не тільки Постанов і звітів, як ми навели приклад вище, а й перевірок контролюючих органів [6, арк. 26].

Перевірки додавали клопоту насамперед керівникам СБЗ, рядові ж студенти сприймали їх переважно з гумором. Алєксєєв В. А., боєць будівельного загону «Електрон» Харківського інституту радіоелектроніки, пригадує, що в загін із перевіркою приїхав інспектор, викладач кафедри охорони праці XIPE А. Скирта. Зовні він виглядав дуже худим і замкнутим. За спиною в нього величезний досвід роботи в будівельних загонах. До того ж він був дуже принциповою людиною, прискіпувався до всіх дрібниць і чіплявся до всього. Від його інспекції нічого гарного в загоні не чекали. Загін працював у селищі Уват Чебутанського району Ханти-Мансійського округу й розміщався на болоті. Навколо кожної служби загону був дерев'яний настил, по якому могла пройти лише одна людина. На перше питання перевіряльника: «Ну, як справи?» - командир, підморгнувши бійцям, відповів: «Усе дуже добре. Єдине, повадився до них ведмідь. Ось нещодавно задрав корову». Інспектор послухав і вирішив піти самостійно оглянути розташування загону, наголосивши, що його супроводжувати не треба. У цей час один зі студентів вивернув кожуха надів його й сховався в кущах. Коли інспектор проходив по хитких дощечках повз нього, той із ревом вивалився йому назустріч. У перевіряльника одразу зникла надмірна пиха, він чимдужче понісся назад і буквально увірвався до штабу. На здивовані погляди студентів перевіряльник сказав, що йому треба негайно повертатися, а зауважень до загону в нього немає $[9$, c. 78$]$.

Наприкінці 1980-х років будзагонівський рух робив активні спроби адаптуватися до нових соціально-економічних реалій, пов'язаних 3 упровадженням ринкових механізмів функціонування народного господарства. Почали застосовуватися нові організаційні форми, відповідно вносилися корективи в договори. Так у 1987 році 53 харківські будівельні загони працювали на об'єктах, застосовуючи метод бригадного підряду, а ще 6 бригад застосовували принцип агроконвеєру [22, с. 84].

У 1988-1991 рр. на території СРСР 3'являються цілорічні СБЗ. Учасники таких загонів налагоджували ділові партнерські відносини 3 підприємствами й будівельними організаціями та розробляли змінний графік відвідування лекцій та праці. Ініціаторами такого руху стали студенти харківських вузів.

У 1983 році на XX обласному зльоті студентських загонів секретар комітету комсомолу Харківського інституту інженерів комунального господарства М. Буряк вніс пропозицію укладати довгострокові договори, адже це дає можливість ефективніше використовувати працю студентів у тих організаціях, де вони вже працювали минулого літа і де умови й технологічні характеристики об'єкта вже знайомі студентам. Підтвердженням високої ефективності довгострокових договорів були приклади роботи загону ХІІКБу в радгоспі «Шебелинський», в якому загін «Супутник» працював 8 років і кожного року на одну третину збільшував виконання обсягу робіт. Обласний штаб підтримав ініціативу й активно поширював досвід з укладання довгострокових договорів [7, арк. 18].

Загострення соціально-економічної кризи в період перебудови зумовило загострення суперечностей і в СБЗ. Задекларована урядом у 1985 році політика приско- 
рення, тобто інтенсифікація виробництва, зумовила зниження необхідності використання студентських загонів. Із середини 1980-х років дедалі частіше відбуваються зменшення обсягів виробництва СБЗ, або ж керівники організацій повністю відмовляються укладати договори із СБЗ та використовувати їх працю [11, с. 131].

Так, від прийому студентів-провідників відмовилося управління Жовтневої залізниці, а Харківський обласний загін у 1987 році виконав обсяг робіт, менший за минулорічний майже на 4 млн крб. [20, c. 83].

У кінці 1980-х рр. будзагонівський рух робив активні спроби адаптуватися до нових соціально-економічних реалій, пов'язаних із упровадженням ринкових механізмів функціонування народного господарства. У цей період у роботі СБЗ впроваджувалися нові організаційні форми. У 1987 р. в Харкові було створено два студентських ринки, на яких була реалізована сільгосппродукція на загальну суму 220 тис. карб. Важливим напрямом трансформації роботи СБЗ стала спроба переходу на госпрозрахункові відносини. Так у травні 1989 року за рішенням комітету комсомолу й обласного штабу студентських загонів у Харківському політехнічному інституті було створено госпрозрахунковий штаб трудових об'єднань молоді на чолі 3 К. Карапетяном. Ця організація, головним завданням якої було працевлаштування молоді, мала самостійний юридичний статус, баланс і розрахунковий рахунок [20, с. 84].

Ці спроби й нові форми організації дали новий досвід, але не могли врятувати від занепаду студентський будівельний рух. Як зазначають дослідники, у молодіжному русі середини 80-х років назріла катастрофічна криза, яка проявилася в стрімкому зростанні протестних настроїв та популяризації неформальних об’єднань, до складу яких у 1986 році вже входило близько $13 \%$ радянської молоді $[8$, с. 8$]$.

$\mathrm{y}$ критичних умовах опинився рух студентських будівельних загонів в умовах економічних трансформацій початку 1990-х років. Шокова терапія привела до скорочення промислового виробництва на Україні на $55 \%$, а сільського господарства - на $30 \%$.
Рівень безробіття досяг $40 \%$ [2, с. 48].

У таких умовах робота СБЗ стала нерентабельною й незатребуваною. У 1998 1991 pр. на території СРСР спостерігалися й такі тенденції розвитку студентського будівельного руху, як перехід на добровільний принцип формування, посилення професійної підготовки, створення цілорічних трудових загонів [13].

Спроби реформування студентського будівельного руху мали певні позитивні ознаки, але були призупинені у зв'язку 3 розпадом всієї системи в 1991 році.

Таким чином, головною причиною занепаду СБ3 стала економічна ситуація в країні на початку 1990-х рр., яка призвела до занепаду основних галузей народного господарства, що забезпечували діяльність трудових загонів.

Деякі сучасні українські дослідники, серед них і К. Астахова, вважають, що відродження цього молодіжного руху сприяло б професійному, соціальному й культурному розвитку молоді [22, с. 7]. I дійсно, у наш час в окремих регіонах колишнього СРСР це явище певною мірою відновлюється.

Зокрема, у вищих навчальних закладах України з 2002 року частково відновлено процес створення й активної діяльності молодіжних трудових загонів та секторів працевлаштування. Молодіжні трудові загони з'являються в сучасних вищих навчальних закладах відповідно до Положення про Молодіжні трудові загони, затвердженого спільним наказом Державного комітету України у справах сім'ї та молоді, Міністерства праці та соціальної політики України, Міністерства освіти і науки України від 15.02.2002 р. № 31/105/95.

За даними управління у справах молоді та спорту Харківської обласної державної адміністрації у 2015 році було створено 165 молодіжних трудових загонів (у межах Харківської області - 150, за межами області - 15), із загальною кількістю учасників 6781 осіб, з них 5757 осіб - студенти, 939 осіб - старшокласники, 41 особа - незайнята молодь [16].

Якщо говорити про інші пострадянські країни, то можна виокремити Казахстан. Слід зазначити, що ставлення корін- 
них мешканців до освоєння цілинних земель було неоднозначним за часів СРСР, як i їх сучасна реакція на відродження цього руху. Зокрема, учасник СБЗ Харківського інституту інженерів комунального будівництва Б. Зеленський у своїх спогадах зазначає, що деякі казахи були категорично проти розорювання земель, будівництва нових об'єктів народного господарства в Казахстані та втручання в їхню субкультуру. Найчастіше ці протести виражалися у формі пошкодження або знищення результатів праці студентських будівельних загонів. Студентам доводилося організовувати цілодобове чергування біля об'єктів будівництва, щоб унеможливити підпали, які влаштовували місцеві $[10$, с. 56].

Думка сучасних експертів із Казахстану щодо відновлення студентських будівельних загонів також часто $є$ полярною. Так, учасник експертного клубу «Світ Свразії» С. Домнина вважає, що відродити рух СБ3 в колишніх масштабах не вийде, адже існування цього явища визначала планова економіка й завдання по будівництву численних об'єктів. Це дозволяло задіяти студентів як сезонних працівників, які не мали кваліфікації. Зараз дефіциту в некваліфікованій праці практично немає, навпаки - не вистачає вузьких фахівців [15].

Такої ж думки i професор Казахстансько-Німецького університету Р. Бурнашев. Він вважає, що роботодавцям невигідно брати сезонних працівників-студентів, дешевше найняти гастарбайтерів, тому в умовах ринкової економіки студентські загони можуть розглядатися як предтеча нового руху, в якому буде і професійна, й ідеологічна складова [15].

У той же час в Казахстані з 2005 року почали створюватися молодіжні трудові загони «ЖасилЕл» і студентські будзагони. У Росії з 2004 року діє громадська організація, яка об’єднує студентські загони країни. Окрім того, у Білорусі, Казахстані та Росії висунуті ідеї про створення в 20192020 роках міжнародних молодіжних трудових загонів.

Із 1 вересня 2019 р. в Казахстані діє механізм, який можна вважати якимось новим прочитанням трудової мобілізації студентів. Міністерство освіти і науки країни вводить волонтерські ваучери для студентів, за рахунок яких частково буде погашатися оплата навчання у вишах. Також заплановано підвищення стипендії на $30 \%$ студентам-волонтерам [15].

Висновок. На основі аналізу широкого комплексу джерел можна дійти висновку, що вивчення історії студентського будівельного руху залишається одним із важливих напрямів історичних досліджень. Завдяки йому можна уникнути помилок в організації молодіжного руху сьогодні й у той же час ефективніше використовувати досвід СБ3, щоб стимулювати інтерес сучасних студентів до трудової діяльності, надати ім можливість не тільки отримати додатковий заробіток, але й чітко усвідомити своє місце в житті суспільства та країни.

\section{ЛІТЕРАТУРА}

1. Артемьев Е. Ф. Студенческие отряды и коммунистическое воспитание молодежи. История, опыт патриотического движения студенческой молодежи (1959-1975). Уч. пос. / Е.Ф.Артемьев. М.: ВКШ при ЦК ВЛКСМ, 1978. 105 с.

2. Алексєєв С. Формування ринку пращуі в Украӥні в 1991-2004 рр.: історичні особливості та наслідки / С. Алексєєв // Схід: аналітично-інформаційний журнал. 2012. №5(119). С. 76-80.

3. Бовкун В. В. Образ жизни советской молодежи: тенденции, проблемы, перспективы. Моногр. / В. В. Бовкун. М.: Высшая школа, 1988. С. 140.

4. Державний архів Харківської області, Ф. П-14 on. 25 , сnр. 59.

5. Державний архів Харківської області, Ф. П-14 on. 27, cnp. 61.

6. Державний архів Харківської області, Ф. П-14, on. 23 , cnp. 83.

7. Державний архів Харківської області, Ф. П-14, on. 25 , сnр. 61.

8. Емельянов В. А. Политическая социализация молодежи в период перестройки / В. А. Емельянов // Историческая наука. 2012. Bып. 1. T. 2. С. 6-8.

9. Это наша с тобой биография.: очерки истории студенческого строительного движения Харьковщины / сост.: М. П. Дуравкин и др. Х.: Точка, 2008. 112 c.

10. Зеленський Б. К. Колоски в сиреневом тумане / Б. К. Зеленский // Наш сучасник: літ.-худож. альманах. Вип. 8. На обрї̈ майбуття / [В. М. Бабаєв, Л. М. Шутенко, В.П. Бурмака, та ін.]; упор. М. Г. Ягубян; Харк. нац. ун-т. міськ. госп-ва ім. О. М. Бекетова. Х.: ХНУМГ, 2013. С. 53-60.

11. Иваненков С. П. Студенческие трудовые отрядbl: опьт, анализ, перспективы / С. П. Иваненков, И. Е. Сазонов. Санкт-Петербург: Питер, 
2001 [Електронний ресурс]. Режим доступу: http://ivantnkovs.narod.ru

12. Иваненков С. П. Студенческие трудовые отряды: опыт, анализ, перспективы / С. П. Иваненков, И. Е. Сазонов. СПб., 2002.

13. История стройотрядов [Электронный ресурс]. Режим достуnа: http://www.dmmari.ru/print:stroyotryady-hist.html

14. КПСС о комсомоле и молодежи. Сборник резолюиий решений съездов, конферениий партии, постановлений ЦК КПСС и других партийных документов (1917-1961). М.: Молодая гвардия, 1962. 432 c.

15. Мир Евразии / 60 лет студенческим стройотрядам. Феномен, возникший на казахстанской земле [Электронный ресурс]. Режим доступа: https://www.ritmeurasia.org/news--2019-07-27--60let-studencheskim-strojotrjadam.-fenomenvoznikshij-na-kazahstanskoj-zemle-44032.

16. Молодіжні трудові загони 2015 року [Електронний ресурс]. Режим доступу:

http://dmskh.gov.ua/novini/1226-molodizhnitrudovi-zagoni-2015-roku

17. Никитинский Л. В. Студент в рабочей спецовке. С. 4; Артемьев Е. Ф. Студенческий отряд. Вопросы и ответы. М.: Молодая гвардия, 1987. $231 \mathrm{c}$.

18. Платонов Ю. П. Соииально-психологические аспекты управления студенческими трудовыми коллективами: Учебное пособие / Ю. П. Платонов. Л.: Изд-во Ленинградский ун-т, 1986. $186 \mathrm{c.}$

19. Платонов Ю. П. Студенческие отряды: психологические очерки / Ю. П. Платонов. Л.: Изд-во Ленинградский ун-т, 1988. 174 c.

20. Ралко Р. С. Студентський будівельний загін вищих навчальних закладів м. Києва (19621991 рр.): дис... канд. іст. наук: 07.00.01. / Р. С. Ралко. Київ, 2018.

21. Рябченко О. Л. Студентські будівельні загони: до питання про витоки руху / О. Рябченко // Дослідження з історії $i$ філософії науки $і$ техніки. 2018. № 26-27. C. 4-56.

22. Сакара Ю. Трудові семестри політехніків [Електронний ресурс] / Ю. Сакара, В. Ніколаєнко. Режим достуny: http://polytechnic.kpi.kharkov.ua/ files/2011.

23. Студент XXI века: соичальный портрет на фоне общественных трансформащий / под ред. В. И. Астаховой. Х.: Изд-во НУА, 2010. 408 c.

24. Студенческие строительные отряды: вчера, сегодня, завтра / [В.И. Астахова, E. В. Астахова, А. А. Гайков и др.]; Департамент образования и науки Харьк. обл. гос. админинистрации, Совет ректоров Харьк. вузов. иентра, Нар. укр. акад. Х.: Изд-во НУА, 2013. 475 c.

25. Чупров В. И., Зубок Ю. А., Уильямс К. Молодежь в обществе риска. Второе издание. М.: Наука, 2003.

\section{REFERENCES}

1. Artemiev, E.F. (1978). Studencheskie otriady $i$ kommunisticheskoe vospytanie molodezhy. Istoriya, opyt patrioticheskoho dvyzheniya studencheskoi molodezhy (1959-1975) [Student detachments and communist education of youth. History, experience of the patriotic movement of student youth (19591975)]. Moskow: VKSh pry TsK VLKSM. 105 p. [in Russian].

2. Alekseev, S. (2012). Formuvannia rynku pratsi v Ukraini v 1991-2004 rr .: istorychni osoblyvosti ta naslidky [Formation of the labor market in Ukraine in 1991-2004: historical features and consequences]. Skhid-East, 5 (119), 76-80.

3. Bovkun, V.V. (1988). Obraz zhyzny sovetskoi molodezhy: tendentsyy, problemy, perspektyvy [The way of life of Soviet youth: trends, problems, prospects]: monohrafyia. Moskow: Vysshaia shkola. 140 p. [in Russian].

4. Derzhavnyi arkhiv Kharkivskoi oblasti [State Archives of Kharkiv Region]. F. P-14, op. 25, spr. 59.

5. Derzhavnyi arkhiv Kharkivskoi oblasti [State Archives of Kharkiv Region]. F. P-14, op. 27, spr. 61.

6. Derzhavnyi arkhiv Kharkivskoi oblasti [State Archives of Kharkiv Region]. F. P-14, op. 23, spr. 83.

7. Derzhavnyi arkhiv Kharkivskoi oblasti [State Archives of Kharkiv Region]. F. P-14, op. 25, spr. 61.

8. Emelianov, V.A. (2012). Polytycheskaia sotsyalyzatsyia molodezhy $\mathrm{v}$ peryod perestroiky [Political socialization of youth during perestroika]. Ystorycheskaia nauka - Historical Science, vol. 2, issue 1, 6-8 [in Russian].
9. Duravkyn, M.P. (Ed.). (2008). Eto nasha s toboi byohrafiya: ocherky istoryy studencheskoho stroytelnoho dvyzheniya Kharkovshchiny [This is our biography: essays on the history of the student construction movement of the Kharkiv region]. Kharkov: Tochka [in Russian].

10. Zelenskyi, B.K. (2013). Kolosky v syrenevom tumane [Spikelets in a lilac fog]. Nash suchasnyk Our contemporary: lit.-khudozh. Almanakh, issue 8, 53-60 [in Russian].

11. Yvanenkov, S.P., \& Sazonov, Y.E. (2001). Studencheskye trudovye otriady: opyt, analyz, perspektivy [Student labor teams: experience, analysis, prospects]. Sankt-Peterburh: Pyter. Retrieved from http://ivantnkovs.narod.ru [in Russian].

12. Yvanenkov, S.P., \& Sazonov, Y.E. (2002). Studencheskye trudovye otriady: opyt, analyz, perspektivy [Student labor teams: experience, analysis, prospects]. Sankt-Peterburh: Pyter [in Russian].

13. Istoriya stroiotriadov [History of construction teams]. Retrieved from http://www.dmmari.ru/print:stroyotryady-hist.html [in Russian].

14. KPSS o komsomole i molodezhy: sbornyk rezoliutsyi reshenyi siezdov, konferentsyi partyy, postanovlenyi TsK KPSS i druhykh partyi [CPSU about the Komsomol and youth. Collection of resolutions of decisions of congresses, conferences of the party, resolutions of the Central Committee of the CPSU and other party documents] (1962). Moskow, Molodaia hvardiya [in Russian]. 
15. Myr Evrazyy. 60 let studencheskym stroiotriadam. Fenomen, voznykshyi na kazakhstanskoi zemle [The world of Eurasia. 60 years of student construction teams. The phenomenon that arose on the Kazakh land]. (n.d.). Retrieved from https:// www.ritmeurasia.org/news--2019-07-27--60-letstudencheskim-strojotrjadam.-fenomen-voznik shijna-kazahstanskoj-zemle-44032 [in Russian].

16. Molodizhni trudovi zahony 2015 roku [Youth labor detachments of 2015]. (n.d.). Retrieved from http://dmskh.gov.ua/novini/1226-molodizhnitrudovi-zagoni-2015-roku.

17. Nykytynskyi, L.V. (1987). Student v rabochei spetsovke [Student in work uniform]. Studencheskyi otriad. Voprosy i otvety - Student squad. Questions and answers. E.F. Artemiev (Ed.). Moskow, [in Russian].

18. Platonov, Y.P. (1986). Sotsyalno-psykholohycheskye aspekty upravlenyia studencheskymy trudovymy kollektyvamy [Socio-psychological aspects of student labor collectives management]. Leningrad: Yzd-vo Lenynhradskyi un-t [in Russian].

19. Platonov, Y.P. (1988). Studencheskye otriady: psykholohycheskye ocherky [Student teams: psychological essays]. Lenyngrad: Yzd-vo Lenynhradskyi un-t [in Russian].

20. Ralko, R.S. (2018). Studentskyi budivelnyi zahin vyshchykh navchalnykh zakladiv m. Kyieva (1962-
$1991 \mathrm{rr}$.) [Student construction detachment of higher educational institutions of Kyiv (1962-1991)]. Kandidate's thesis. Kyiv.

21. Riabchenko, O.L. (2018). Studentski budivelni zahony: do pytannia pro vytoky rukhu [Student construction units: the question of the origins of the movement]. Doslidzhennia z istorii i filosofii nauky $i$ tekhniky - Research in the history and philosophy of science and technology, 26-27, 43-56.

22. Sakara, Y., \& Nikolaienko, V. (n.d.). Trudovi semestry politekhnikiv [Labor semesters of polytechnics]. Retrieved from http://polytechnic.kpi.kharkov.ua/ files/2011.

23. Astakhova, V.Y. (Ed.). (2010). Student XXI veka: sotsyalnyi portret na fone obshchestvennykh transformatsyi [Student of the XXI century: a social portrait against the background of social transformations]. Kharkov: Yzd-vo NUA [in Russian].

24. Astakhova, V.Y., Astakhova, E.V., \& Haikov, A.A. et al. (2013). Studencheskye stroytelnye otriady: vchera, sehodnia, zavtra [Student construction teams: yesterday, today, tomorrow]. Kharkov: Yzdvo NUA [in Russian].

25. Chuprov, V.Y., Zubok, Y.A., \& Uyliams, K. (2003). Molodezh $v$ obshchestve ryska [Youth in a risk society]. (2nd ed.). Moskow: Nauka [in Russian]. 